\title{
Hypertension associated with increased renin concentrations in nephroblastoma
}

\author{
A B Khan, R Carachi, B J Leckie, G B M Lindop
}

\begin{abstract}
An infant with severe hypertension who had a nephroblastoma which was secreting active renin is described. Nephroblastoma must be included in the differential diagnosis of hypertension associated with increased renin concentrations, even in the absence of an abdominal mass.
\end{abstract}

Hypertension has been known to be associated with nephroblastoma since it was first reported in 1937 by Pincoffs and Bradley. ${ }^{1}$ The incidence of hypertension has been reported as high as $60 \%$ in some series. ${ }^{2}$ This was commonly thought to be due to catecholamine production. Recently, however, several cases of nephroblastoma have been reported with raised renin concentrations. This excess renin production may be from normal renal tissue as a consequence of distorted renal vasculature by tumour compression or it may be from the tumour itself. We report a case of nephroblastoma with severe hypertension with raised renin concentrations where tumour immunohistochemistry demonstrated perivascular renin containing cells.

\section{Case report}

A 10 month old boy presented with a two week history of malaise and anorexia. On examination he was irritable and flushed, and noted to be severely hypertensive with a blood pressure of $250 / 194 \mathrm{~mm} \mathrm{Hg}$. His pulse was $100 /$ minute with no radial-femoral difference. A large irregular left sided abdominal mass was palpated. Biochemical analysis showed a sodium concentration of $131 \mathrm{mmol} / \mathrm{l}$, potassium of $3.7 \mathrm{mmol} / 1$, and urea of $9.5 \mathrm{mmol} / \mathrm{l}$. An intravenous pyelogram and computed tomogram confirmed this mass to be arising from the left kidney. Hydroxymethyl mandelic acid and vanillyl mandelic acid markers for neuroblastoma were 16 and 24 $\mu \mathrm{mol} / \mathrm{mmol}$ creatinine respectively (normal). Blood was also taken to measure renin concentrations.

Initial attempts at control of blood pressure with intravenous labetalol and hydralazine were unsuccessful, and so nine days after admission laparotomy was performed. Captopril, an acetyl coenzyme inhibitor, was given at induction with a good fall in blood pressure. A large nephroblastoma extending $5 \mathrm{~cm}$ down the ureter but with no macroscopic capsule invasion was removed. The right kidney felt normal.

Postoperatively the boy made a good recovery. His blood pressure fell to normal by the second postoperative day and his antihyperten- sive medication was stopped. The patient was given vincristine and actinomycin $D(0.025$ $\mathrm{mg} / \mathrm{kg}$ of each) for 26 weeks according to the United Kingdom Children's Cancer Study Group protocol and is well one year postoperatively.

\section{Methods and results RENIN ASSAY}

Preoperatively and one week postoperatively, blood was taken for measurement of renin concentration. Active and total renin were measured by the method of Millar et al. ${ }^{3}$ For active renin, $35 \mu \mathrm{l}$ of plasma was incubated at $37^{\circ} \mathrm{C}$ in duplicate with excess ox renin substrate and antibody to angiotensin 1 at $\mathrm{pH} 6.9$. The rate of generation of angiotensin 1 was measured by radioimmunoassay and the results calibrated against a preparation of international standard renin. ${ }^{4}$ For total renin, the plasma was treated with trypsin in order to convert the prorenin to renin. At very high concentrations of renin, this can lead to a slightly low figure for total renin because of renin degradation by trypsin and problems with the dilutional technique. Inactive renin was calculated as total renin-active renin.

Total renin and particularly active renin concentrations were found to be grossly raised preoperatively at $13385 \mu \mathrm{U} / \mathrm{ml}$ and $9674 \mu \mathrm{U} / \mathrm{ml}$ respectively (normal $50 \mu \mathrm{U} / \mathrm{ml}$ and $200 \mu \mathrm{U} / \mathrm{ml}$ ). Postoperatively these fell to 8 and $55 \mu \mathrm{U} / \mathrm{ml}$.

\section{HISTOLOGY}

The specimen weighed $635 \mathrm{~g}$ and measured $17 \times$ $10 \times 9 \mathrm{~cm}$. The tumour was a moderately well differentiated nephroblastoma predominantly blastemal in type but with prominent glomeruloid structures and some areas of increased tubular differentiation, and was classified as stage 2 favourable histology.

Using an antibody to pure renin and a peroxidase-antiperoxidase technique, ${ }^{5}$ most of the cells containing immunoreactive renin were present in a perivascular position in the blastemal areas as previously described. ${ }^{5}$ Within the glomeruloid structures there were some renin containing cells in a mesangial distribution. These cells contained granules that stained positively for renin and their appearance suggested that they were renin secreting cells.

\section{Discussion}

In the case reported, active renin was raised 50fold preoperatively and fell postoperatively to 
Cases of nephroblastoma associated with hypertension and raised renin concentration

\begin{tabular}{|c|c|c|c|c|c|c|}
\hline \multirow[t]{2}{*}{ Author } & \multirow[t]{2}{*}{ Age } & \multirow[t]{2}{*}{ Sex } & \multirow{2}{*}{$\begin{array}{l}\text { Side } \\
(R, \text { right } ; \\
L, \text { left })\end{array}$} & \multirow{2}{*}{$\begin{array}{l}\text { Blood } \\
\text { pressure } \\
\text { (mm } \mathbf{H g})\end{array}$} & \multicolumn{2}{|c|}{ Renin concentration $(\mu U / m l)$} \\
\hline & & & & & Preoperative & Postoperative \\
\hline 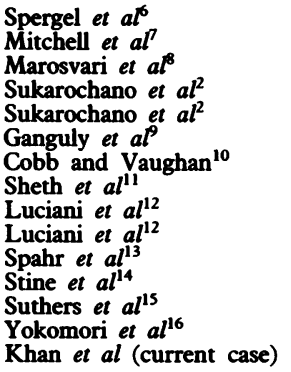 & $\begin{array}{r}5 \text { months } \\
23 \text { months } \\
18 \text { months } \\
4 \cdot 5 \text { years } \\
5 \text { years } \\
4 \text { years } \\
27 \text { months } \\
16 \text { months } \\
3 \text { years } \\
4 \text { years } \\
4 \text { years } \\
9 \text { months } \\
2 \text { years } \\
9 \text { months } \\
10 \text { months }\end{array}$ & $\begin{array}{l}\mathbf{F} \\
\mathbf{M} \\
\mathbf{M} \\
\mathbf{M} \\
\mathbf{M} \\
\mathbf{M} \\
\mathbf{M} \\
\mathbf{M} \\
\mathbf{M} \\
\mathbf{M} \\
\mathbf{M} \\
\mathbf{M} \\
\mathbf{F} \\
\mathbf{M}\end{array}$ & $\begin{array}{l}\mathbf{R} \\
\mathbf{R} \\
\mathbf{L} \\
\mathbf{L} \\
\mathbf{R} \\
\mathbf{R} \\
\mathbf{R} \\
\mathbf{R} \\
\mathbf{L} \\
\mathbf{L} \\
\mathbf{L} \\
\mathbf{L}+\mathbf{R} \\
\mathbf{L} \\
\mathbf{L}+\mathbf{R} \\
\mathbf{L}\end{array}$ & $\begin{array}{l}210 / 160 \\
260 / 200 \\
160 / 120 \\
200 / 110 \\
162 / 128 \\
200 / 140 \\
210 / 140 \\
200 / 120 \\
200 / 120 \\
210 / 140 \\
170 / 120 \\
162 / 110 \\
220 / 148 \\
140 / 90 \\
250 / 194\end{array}$ & $\begin{array}{l}14 \cdot 5 \\
12 \cdot 3 \\
15 \cdot 0 \\
16.000^{*} \\
810 \\
10 \cdot 1 \\
\text { Raised } \\
39 \cdot 5 \\
51 \cdot 0 \\
3 \cdot 4 \\
8 \cdot 8 \\
51 \cdot 9 \\
5 \cdot 2 \\
99 \cdot 0 \\
268\end{array}$ & $\begin{array}{l}2 \cdot 8 \\
0 \cdot 66 \\
7 \cdot 0 \\
220^{*} \\
0.09 \\
\text { ND } \\
1 \cdot 6 \\
1 \cdot 1 \\
0 \cdot 47 \\
0 \cdot 35 \\
0 \cdot 77 \\
0 \cdot 33 \\
0 \cdot 05 \\
0 \cdot 16\end{array}$ \\
\hline
\end{tabular}

*No normal values stated, units are ng. ND, not done.

within normal limits as did the blood pressure. The inactive form was also raised but not to the same degree. The renin was found to be arising from the tumour.

The first association of nephroblastoma with raised serum renin concentrations was in $1969 .^{6}$ The case reported was a 5.5 month old child with a blood pressure of $210 / 160 \mathrm{~mm} \mathrm{Hg}$ associated with hypokalaemia, abnormal glucose tolerance, and increased renin concentrations. Mitchell et al demonstrated raised renin concentrations in tumour tissue as well as serum in a 23 month old child with hypokalaemia and a blood pressure of $260 / 200 \mathrm{~mm} \mathrm{Hg}{ }^{7}$ This was thought to be evidence of abnormal renin production from the tumour rather than as a result of an ischaemic stimulus to the renin angiotensin system in the rest of the kidney. Since that report of Mitchell et al there have been 12 other reports of nephroblastoma associated with hypertension and increased renin concentrations (table). There is a sex ratio of four males to one female and the average age is 3 years. The time taken for the blood pressure to fall in most cases was between one and three weeks after nephrectomy. This time appears unrelated to the presence or subsequent development of metastases.

There have been a number of cases of nephroblastoma with increased concentrations of renin who were normotensive. Renin production was looked at in eight children with nephroblastoma by Voute et al. ${ }^{17}$ Blood pressure was normal in all eight while the serum renin concentration was found to be raised. In the five studied postoperatively, there was noted to be a fall in serum renin after nephrectomy. Day et al found renin in tissue from nephroblastoma with a much greater molecular weight than normal plasma and kidney renin. ${ }^{18}$ They suggested the existence of an inactive prohormone and this inactive form of renin could account for the large number of cases of nephroblastoma which are not associated with hypertension. Carachi et al looked prospectively at eight children with nephroblastoma measuring both active and inactive renin. ${ }^{19}$ In seven of these cases there was found to be a raised concentration of serum renin. However, this increased amount was seen to comprise mainly the inactive form. Only one child was hypertensive.

Nephroblastoma should always be considered as part of the differential diagnosis for hypertension in the young. Renin concentrations should be checked and if found to be raised, a careful search should be made for a nephroblastoma even in the absence of an abdominal massparticularly where there is no evidence of renal parenchymal disease.

We would like to thank Mr AHB Fyfe for permission to present this case. Thanks also to the departments of pathology, radio logy, and medical illustration in the Royal Hospital for Sick Children, Glasgow.

1 Pincoffs MC, Bradley JE. The association of adenosarcoma of the kidney (Wilms' tumor) with arterial hypertension. Trans Assoc Am Physicians 1937;52:320.

2 Sukarochano K, Tolentino W, Kiesewetter WB. Wilms' tumor and hypertension. F Pediatr Surg 1972;7:573-7.

3 Millar JA, Leckie BJ, Morton JJ, Jordon J, Tree MA. A micro assay for active and total renin concentration in human plasma based on antibody trapping. Clin Chim Acto 1980;101:5-15.

4 Bangham DR, Robertson I, Robertson JIS, Robinson CJ, Tree $M$. An international collaborative study of renin assay: establishment of the international reference preparation of establishment of the international reference preparation of human renin. Clinical

5 Lindop GBM, Fleming S, Gibson AAM. Immunocytochemical localisation of renin in nephroblastoma. $f$ Clin Pathol 1984;37:738-42.

6 Spergel G, Lustik B, Levey LJ, Ertel NH. Studies of hypertension and carbohydrate intolerance associated with Wilms' tumor. Ann Intern Med 1969;70:565-70.

7 Mitchell JD, Baxter TJ, Blair-West JR, McCreadie DA. Renin levels in nephroblastoma (Wilms' tumour). Report of a renin secreting tumour. Arch Dis Child 1970;45: 376-84.

8 Marosvari I, Kontor E, Kallay K. Renin-secreting Wilms' tumour. Lancet 1972;i:1180.

9 Ganguly A, Gribble J, Tune B, Kempson RL, Luetscher JA. Renin secreting Wilms' tumour with severe hypertension. Report of a case and brief review of renin secretin tumours. Amn Intern Med 1973;79:835-7.

10 Cobb $M$, Vaughn $R$. Severe hypertension in a child with Wilms' tumor: a case report. Anesth Analg 1976;55:519-21.

11 Sheth KJ, Tang TT, Blaedel ME, Good TA. Polydipsia, polyuria, and hypertension associated with renin secreting polyuria, and hypertension associated with

12 Luciani JC, Baldet P, Dumas R, Jean R. Etude du systeme renine-angiotensine dans deux cas de tumor de Wilms avec renine-angiotensine dans deux cas de tumor de Wr lims avec 240-9.

13 Spahr J, Demers LM, Shochoat SJ. Renin producing Wilms' tumor. F Pediatr Surg 1981;16:32-4.

14 Stine KC, Goertz KK, Poisner AM, et al. Congestive hear failure, hypertension and hyperreninaemia in bilatera Wilms' tumor: successful medical management. Med Pediat Oncol 1986;14:63-6.

15 Suthers GK, Roy LP, Stevens M. Control of nephroblastoma: associated hypertension and polydipsia by captopril. Aust Paediatr $\mathcal{J}$ 1987;23:245-6.

16 Yokomori K, Hori T, Takemura T, Tsuchida Y. Demonstro tion of both primary and secondary reninism in rena tumours in children. I Pediatr Surg 1988;23:403-9.

17 Voute PA, van der Meer J, Staugaard-Kloosterziel W. Plasm renin activity in Wilms' tumour. Acta Endocrinol (Copenh) 1971;67:197-202.

18 Day RP, Luetscher JA, Gonzales CM. Big renin: a possible prohormone in kidney and plasma of a patient with Wilms tumor. F Clin Endocrinol Metab 1974;38:923-6.

19 Carachi $R$, Lindop GBM, Leckie BI. Inactive renin: a tumor marker in nephroblastoma. F Pediatr Surg 1987;22:278-80. 